- Short Communication

\title{
ECO-ENVIRONMENTAL CHANGES OF HAIL HAOR WETLAND RESOURCES UNDER SYLHET BASIN OF BANGLADESH DUE TO SEDIMENTATION: A GIS APPROACH
}

\author{
M. J. UDDIN ${ }^{1}$, A. S.M. MOHIUDDIN AND S. T. HOSSAIN ${ }^{2}$ \\ Department of Soil, Water and Environment, University of Dhaka, Dhaka-1000, Bangladesh \\ ${ }^{2}$ Friends In Village Development Bangladesh (FIVDB), Dhaka-1207, Bangladesh
}

Bangladesh is a country of vast wetland resources covering an area of about seven to eight million hectares, which is about $50 \%$ of the total land surface including the flood plains. The greater part of northeast region is taken up by the wetland basin, which comprises the floodplains of the Meghna river tributaries, and is characterized by the presence of numerous large, deeply flooded depressions, between the rivers known as haors. The geology, hydrology, soil characteristics, and socio-economic attributes of the haor basin also contribute to distinguish it from its adjacent hilly lands. It is believed that the basin is technically active and is undergoing subsidence (Morgan and McIntire 1959). During monsoon the basin receives huge discharges of large number of rivers flowing down from the hills of Assam and Meghalaya and takes the form of a vast inland sea. Sylhet basin covers a large number of haors and wetlands and among those Hakaluki haor, Tanguar haor, Hail haor etc cover an extensive area (WRI 1990). This basin is an extensive alluvial plain supporting a variety of wetland habitats. It contains about 47 major haors and more than 6,000 beels, or freshwater lakes, nearly half of which are seasonal (Haque 2008). The major rivers in the study area are the Surma and the Kushiyara and their tributaries Manu, Khowai, Jadukhata, Piyain, Mogra, Mahadao and Kangsha which have formed the dense drainage network of the haors. These hilly rivers coming down from the Khasia and Jaintia hills in Meghalaya carry high volumes of water as they come from some of the rainiest places in the world. The main objective of this paper is to investigate the eco-environmental changes of the hail haor wetland ecosystem using GIS technology.

Hail haor is located in the Sylhet basin between the Balishira and Satgaon hills under the Moulvibazar district of Bangladesh which lies between $24^{\circ} 18^{\prime}-24^{\circ} 26^{\prime} \mathrm{N}$ latitude, $91^{\circ} 38^{\prime}-$ $91^{\circ} 45^{\prime} \mathrm{E}$ longitude. The haor originates from the surrounding hill streams. It is a large shallow lake in a saucer-shaped depression, bounded in the south, east and west by low hills and in the north by the plains of the Manu and Kushiara rivers. The haor is almost encircled by a chain of tea estates and natural forest blocks. The river Gopla flows through the wetland in a north-south direction. In order to compare the area of water body, two time series data sources have been taken. The first one is the topographic maps of Messers Capital Air Survey Ltd. Canada during 1974-75 and revised on the ground during 1982-83 and verified during 1987-88 and also 1989-90. The second one is the

${ }^{1}$ Corresponding author: E-mail: mjuddin66@yahoo.com 
Land and Soil Resources Utilization Guides of SRDI (2003). In addition, aerial photo of 1984 was used for some verification. The scale used for these two data sources was 1:50,000. ARC/GIS version 7.1 was used in preparing the maps and the subsequent spatial analysis.

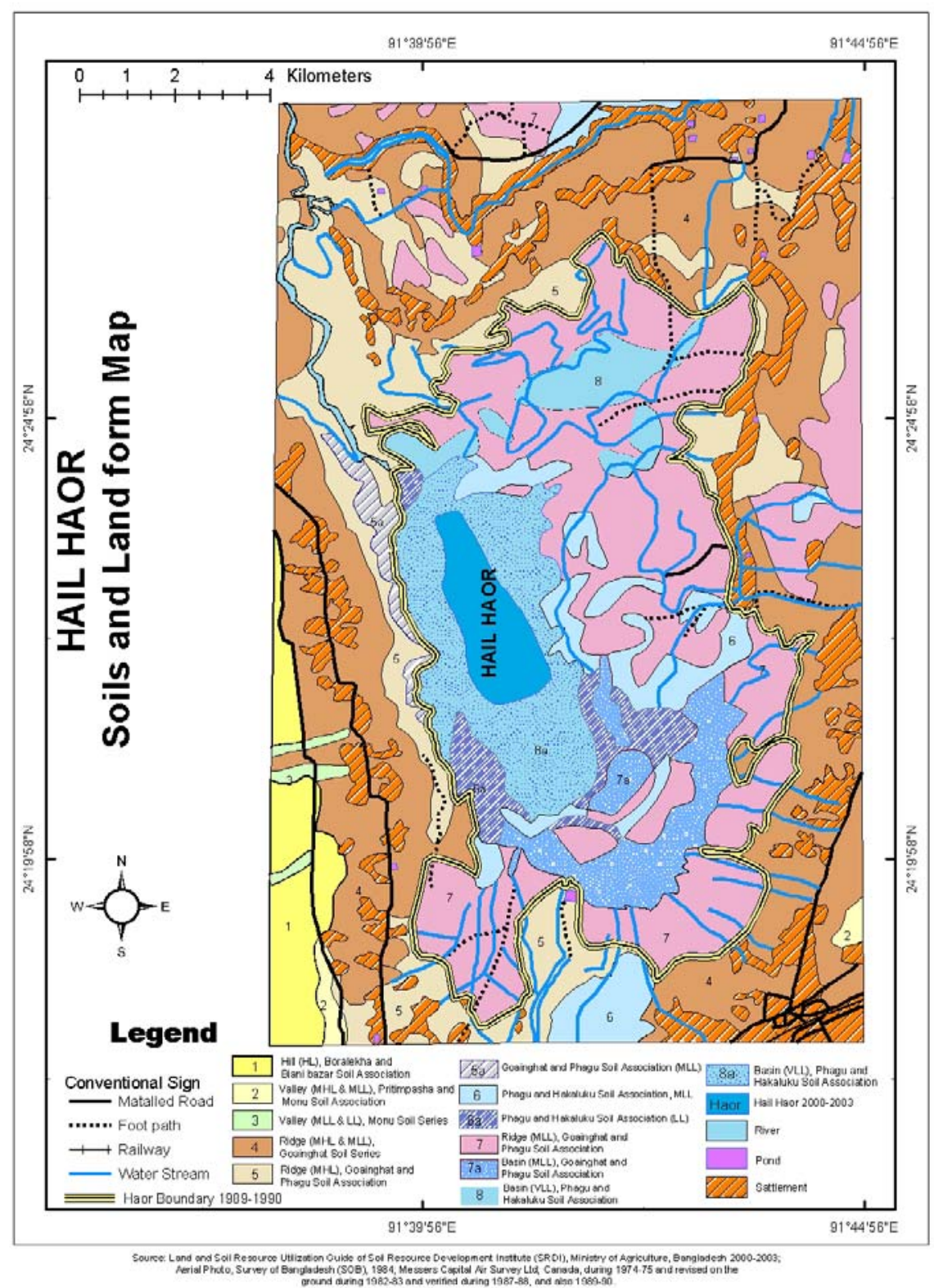

Fig. 1: Soils and landform map of Hail haor under Sylhet basin of Bangladesh. 
It is quite evident that a huge amount of sedimentation has taken place in the study sites. This phenomenon of sedimentation over a time periods introduces new soil boundaries along with HYV rice crops which enhance the shrinkage of the water body. The sedimentation process is accelerated with the flow of upstream water from the surrounding hilly areas. As a result, Goainghat-Phagu soil association and PhaguHakaluki soil association emerge (Fig. 1) where HYV boro rice cultivation is gaining popularity with ultimately shrinking the bio-resources of this wetland. The study revealed that the area covered by wetlands in the hail haor has been significantly reduced over the period from 1989 to 2003 (Figs. 1 and 2)). According to GIS analysis using PAT (Polygon Attribute Tables) files, total hail haor area was about 10,000 ha in 1989, covering the mapping units of $6,6 \mathrm{a}, 7,7 \mathrm{a}, 8$ and $8 \mathrm{a}$ (Fig. 1). In 2003, the area of this water body was reduced and the area becomes 5,200 ha covering the mapping unit $6 \mathrm{a}, 7 \mathrm{a}$ and $8 \mathrm{a}$ (Fig. 1). In 2010, this water ecosystem also decreased significantly and the area of which becomes 2000 ha (Fig. 2). The rate of reduction of the water body is alarming but in the dry season, the area of the Hail haor shrinks further which become 900 ha. The study also shows that considerable changes have occurred due to sedimentation and as a result depth and duration of inundation has changed. This change shows a positive impact on agricultural aspects enhancing emergence of new soil boundaries and serious negative impact on eco-environmental aspects i. e. degradation /reduction of wetland ecosystem. Similar findings were also reported by Hoq and Shoaib (2003) and Sultana et al. (2009) in accretion of land for edaphic use in some flood prone areas of Bangladesh (Erickson et al. 1993). Sedimentation has taken place in low lying areas where grazing land emerges in course of time in some flood prone areas (Ullah et al. 2006). Land use mapping of the surrounding areas of the Hail haor revealed that 46.0 percent is under tea estates, 28.0 percent is forest land and 13.0 percent is privately managed pineapple or other citrus garden (SRDI 2003). These citrus and pineapple gardens disproportionately contributed to siltation because the local farmers habitually grew pineapple and citrus fruits in rows running up-down slope accelerates soil erosion.

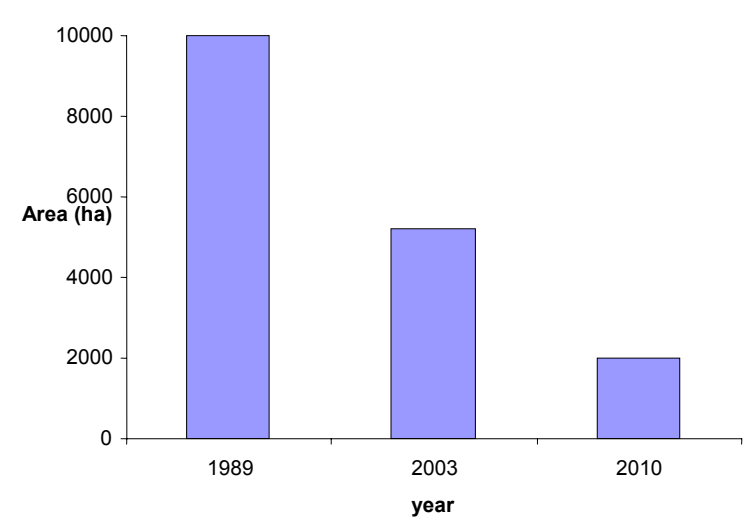

Fig. 2. Decreasing trends of Hail haor wetland ecosystem over the two decades. 
Poor land management in the neighboring hills results in serious soil erosion where pineapple is grown in lines up-downslope. In a study MACH (2004) revealed that Hail haor carried over 2,00,000 $\mathrm{m}^{3}$ of sediment just in July, 1999. In 2001, silt loads of 22 hill stream carried 50,000 tons, suggesting that the total of 59 active hill stream carried over $1,00,000$ tons of silt into Hail haor each year. Deposition of $8-15 \mathrm{~cm}$ of silt in one year was recorded near the outfalls of the hill streams, suggesting that the haor bed is rising on an average by about $5 \mathrm{~cm}$ per year (MACH 2004). Hail haor is changing rapidly, the fringes of the haor are rapidly being filled in and it is apprehended that in near future it may disappear.

\section{References}

Erickson, N. J., Q. K. Ahmed. and A. R. Chowdhury. 1993. Socio-economic implications of climate change for Bangladesh. Bangladesh Unnayan Parishad (BUP). Brief Doc. No. 4, Dhaka. p.37.

Haque, M. I. 2008. Water Resources Management in Bangladesh. Charu Ferdousi Naima for Anushilan, Dhaka. Dhaka. Pp. 218-245.

Hoq, M. M. and J. U. Shoaib. 2003. Edaphological Change due to Sediment: A case study in Savar Area. J. Asiat Soc. Bangladesh. Sci. 29(2): 27-36.

MACH (Management of Aquatic Ecosystem through Community Husbandry), 2004. Hydrology study report. Winrock International, Dhaka. Pp. 5-25.

Morgan, J. P. and W. G. McIntire. 1959. Quaternary Geology of Bengal Basin East Pakistan and India. Bull. Geo. Soc. Am. 70. P. 330.

SRDI (Soil Resource Development Institute), 2003. Land and Soil Resource Utilization Guides of Srimangal Upazila. Ministry of Agriculture, Bangladesh. P. 90

Sultana, M. S., G. M. T. Islam. and Z. Islam. 2009. Application of Geo-informatics in Identifying Reduction of Wetlands in Dhaka. Ban. J. of Water Resources Research. 21:17-28. Dhaka

Ullah, M. S., M. J. Uddin and S. F. Elahi. 2006. Changes in Spatial Patterns of Land and Soil Resources at Mithamoin Upazila under Sylhet Basin of Bangladesh. Dhaka University J. Biol. Sci. 15(2): 105-111.

WRI (World Resources Institute), 1990. Centre for International Development and Environment; Bangladesh Environment and Natural Resource Assessment, Draft Report. Washington DC, USA. Pp. 86. 